\title{
Catalytic fullerenol action on Chlorella growth in the conditions of limited resource base and in the conditions of oxidation stress
}

\author{
L. V. Gerasimova ${ }^{1}$, N. A. Charykov ${ }^{1,2}$, K. N. Semenov ${ }^{1,3}$, V. A. Keskinov ${ }^{1}$, A. V. Kurilenko ${ }^{1}$, \\ Zh. K. Shaimardanov ${ }^{4}$, B. K. Shaimardanova ${ }^{4}$, N. A. Kulenova ${ }^{4}$, D. G. Letenko ${ }^{5}$, Ayat Kanbar ${ }^{1}$ \\ ${ }^{1}$ Saint Petersburg State Technological Institute (Technical University), Moskovsky prospect, 26, \\ Saint Petersburg, 190013, Russia \\ ${ }^{2}$ Saint Petersburg Electrotechnical University “LETI”, ul. Professora Popova 5, 197376, \\ Saint Petersburg, Russia \\ ${ }^{3}$ Saint Petersburg State University, 7/9 Universitetskaya emb., Saint Petersburg, 199034, Russia \\ ${ }^{4}$ D. Serikbayev East Kazakhstan state technical university, A. K. Protozanov Street, 69, \\ UstKamenogorsk city, 070004, The Republic of Kazakhstan \\ ${ }^{5}$ Saint Petersburg State University of Architecture and Civil Engineering (SPSUACE), \\ 2nd Krasnoarmeiskaya St. 4, 190005, Saint Petersburg, Russia \\ keskinov@mail.ru
}

PACS 61.48.+c

DOI 10.17586/2220-8054-2021-12-3-346-362

Catalytic fullerenol $\mathrm{C}_{60}(\mathrm{OH})_{24}$ action on Chlorella Vulgaris growth in the conditions of limited resource growth base and in the conditions of oxidative stress are reported. Chlorella growth or oppression were investigated in open transparent in the visible area cylindrical polystyrene test tubes at room temperature under illumination by standard incandescent lamp for the period 9 days. Catalyst concentration were varied in the range $0.01-1.0 \mathrm{~g} / \mathrm{dm}^{3}$. Oxidative stress was organized by the addition of hydrogen peroxide with the concentration $1.0 \mathrm{~g} / \mathrm{dm}^{3}$. Chlorella Vulgaris concentrations were determined by the method of turbidimetry - by the determination of optical density of scattered light in the direction of propagation of the incident beam at wavelength $664 \mathrm{~nm}$. Obtained kinetic data were processed by the method of formal classical kinetics. The pseudo-order of the process Chlorella Vulgaris growth in the conditions of limited resource, according to Chlorella, is -2 ; the curve of the dependence of Chlorella concentration against time is concave at all fullerenol concentrations. The pseudo-order of the process Chlorella Vulgaris suppression in the conditions of oxidative stress, according to Chlorella, is +2 , the curve of the dependence of Chlorella concentration against time is convex at all fullerenol concentrations. The kinetics of Chlorella Vulgaris growth in the conditions of limited resource was also processed by model Verhulst equation of logisitic growth, and this equation describes the kinetics as accurately and adequately as possible. The authors have established, that in the case of the conditions of limited resource, fullerenol at low concentrations (less than $0.1 \mathrm{~g} / \mathrm{dm}^{3}$ ) catalyzes-accelerates Chlorella growth and at higher concentrations $\left(0.1-1.0 \mathrm{~g} / \mathrm{dm}^{3}\right)$ inhibits Chlorella growth. For the conditions of oxidative stress, authors have established, that at all fullerenol concentrations, it considerably inhibits suppression-depopulation of Chlorella processes, so fullerenol proves enough strong anti-oxidant action. It was demonstrated, that Verhulst equation maybe satisfactory used for the description of different natural process.

Keywords: fullerenol, catalyst, inhibitor, hydrogen peroxide, Chlorella growth, suppression.

Received: 13 March 2021

Revised: 17 May 2021

\section{Introduction}

Light fullerenes $\left(\mathrm{C}_{60}\right.$ and $\left.\mathrm{C}_{70}\right)$ may be more or less effectively used in different fields of science and technics, but its application is sufficiently limited by practically complete insolubility and incompatibility with water and aqueous solutions. Covalent functionalization is the most reliable way to obtain systems based on fullerenes which are suitable for biomedical applications. It deals with the structures of such molecules can be precisely determined (using Xray crystallography), and their pharmacokinetic and dynamic behavior is better understood. This belongs also to the most of the light fullerene derivatives (halogen, amino, hydro and others). Meanwhile, water soluble fullerenes may be used in more wide ranges of applications: machinery, building, medicine, pharmacology (as the result of compatibility with water, physiological solutions, blood, lymph, liquor, gastric juice), agriculture, crop production, cosmetics. Poly-hydroxylated fullerenes (fullerenols) and adducts of light fullerenes $\mathrm{C}_{60}$ and $\mathrm{C}_{70}$ with carboxylic acids and amino-acids are the perspective bioactive fairly water-soluble fullerene derivatives.

This article continues the series of articles investigating the synthesis, identification and properties of fullerenols. Some articles are devoted to the investigation of the influence of water-soluble fullerene derivatives on plants growth and development and common bioactivity (for example [1-11]). The common conclusion in the part, related to the bio-activity of water soluble adducts of light fullerenes on plant is the following - these derivatives have a beneficial 
effect on grow and development of plants, in any case when using not very high concentrations of the latter $-\mathrm{n} \cdot 10^{2}-$ $\mathrm{n} \cdot 10^{3} \mathrm{~g} / \mathrm{dm}^{3}$.

The question of toxicity of fullerenes themselves, and water soluble fullerenes in particular, is closely related with bio-activity. Toxicity of fullerenes and their derivatives were investigated and discussed widely. In one of the last works $[12,13]$ a detailed and complete overview is given. A bibliography on the theme of fullerene toxicity [14-40] covers quite an extensive number of works over the 20 last years. The main conclusions are the following:

- Numerous further studies have also not shown any adverse or toxic effects of fullerene on organism. According to the Toxicological classification of substances exhibiting toxicity at doses above $1 \mathrm{~g} / \mathrm{kg}$, belong to the class of non-toxic substances. A long experiment was conducted in rats the diet of which added fullerene in the form of solution in olive oil [16]. The experiment lasted 5.5 years, as a control diet with the addition of just olive oil and water. Fullerene almost doubled the life expectancy of rats. Different diets did not affect the dynamics of animal weight, which also indicates the absence of toxic effects in.

- It is shown in [14] that fullerene in the form of water colloidal dispersion also does not show toxic proper-ties, but only shows the properties of antioxidant. This conclusion is based on more than ten years of biological tests of fullerene dispersion in various experiments in vitro and in vitro. It did not reveal any toxic effects (at concentrations from $10^{-9}$ to $10^{-4} \mathrm{~mol} / \mathrm{dm}^{3}$ and at total doses up to $25 \mathrm{mg} / \mathrm{kg}$ ).

- The toxicology of water-soluble derivatives of fullerene has been the subject of many discussions, but the vast majority of works have shown their toxicity is low. So, water-soluble fullerene derivatives do not exhibit acute toxicity in vivo, even at sufficiently high doses. For example, the value for fullerenol in intraperitoneal mice is $1.2 \mathrm{~g} / \mathrm{kg}$ [38,39]. Parenteral administration of the amino-acid derivative to mice at a dose of $80 \mathrm{mg} / \mathrm{kg} \mathrm{had}$ no effect on the behavior and viability of mice for 6 months [16].

- In [12] it was shown, that water solutions of octo-adduct $\mathrm{C}_{60}$ with arginine are characterized by acceptable (i.e., low) toxicity and the only one most concentrated solution (with concentration $0.25 \mathrm{~g} / \mathrm{dm}^{3}$ ) can be characterized by moderate toxicity (at the lower limit).

- Research [41] showed water solubility solutions of $\mathrm{C}_{60}$ no toxicity in in vitro experiments on Chinese hamster V79 cell lines.

- The cytotoxicity of $\mathrm{C}_{60}$ in water solution was noted in the research [42]. It showed that the cytotoxicity of water-soluble fullerene species is a sensitive function of surface derivatization; in two different human cell lines, the lethal dose of fullerene changed over 7 orders of magnitude with relatively minor alterations in fullerene structure.

- Authors [43] showed that $\mathrm{C}_{60}(\mathrm{OH})_{24-26}$ did not show acute or chronic toxic effects in model organisms from four different kingdoms. There was evidence of increased growth and increased life expectancy that could have profound effects in environmental research.

- The antioxidant ability of $\mathrm{C}_{60}(\mathrm{OH})_{24}$ has been shown to modulate the cytotoxic effects of the chemotherapeutic agent, doxorubicin (DOX), which causes ROS-mediated oxidative stress [44-46].

- The biological activity of a number of fullerenols with a different number of hydroxyl groups: $\mathrm{C}_{60}(\mathrm{OH})_{12-14}$, $\mathrm{C}_{60}(\mathrm{OH})_{18-24}, \mathrm{C}_{60}(\mathrm{OH})_{30-38}$, was studied [47]: $\mathrm{C}_{60}(\mathrm{OH})_{12-14}$, was insoluble in water and did not show biological activity when introduced into cell cultures in the form of suspensions. While $\mathrm{C}_{60}(\mathrm{OH})_{18-24}$ was soluble and had maximum antiviral and protective activity.

- Fullerenols used in this work [48] demonstrated negligible toxicity even at high concentrations as a result of a specifically developed manufacturing process.

The following property of water soluble fullerene derivatives, which is closely connected with bio-activity is anti-oxidant activity, which was investigated in many works, in particular [3,49-64]. The antioxidant properties of fullerenols were previously investigated. Several mechanisms for the antioxidant activity of fullerenol nanoparticles have been proposed [4]. All authors note very strong anti-oxidant activity of all water soluble fullerene derivatives. However, authors $[49,51]$ determined this bulk anti-oxidant activity weaker one in comparison with such classical anti-oxidant agents as ascorbic acid. But these derivatives possess one very rare and useful property, namely - the ability to reversible absorption of oxidant particles, or to multiple sorption-desorption oh the last ones.

In the present article, we report about the investigation of fullerenol of light fullerene $\mathrm{C}_{60}(\mathrm{OH})_{24}$ in bio-testing, using as test micro-organism "Chlorella vulgaris beijer" - a very popular alga for laboratory studies. We shall report about the kinetics in the system: chlorella vulgaris beijer (bio-component)-fullerenol (catalyst-inhibitor)-water (solvent) in the presence of light (visional region wavelength) and $\mathrm{CO}_{2}$ (dissolved in water solution). 


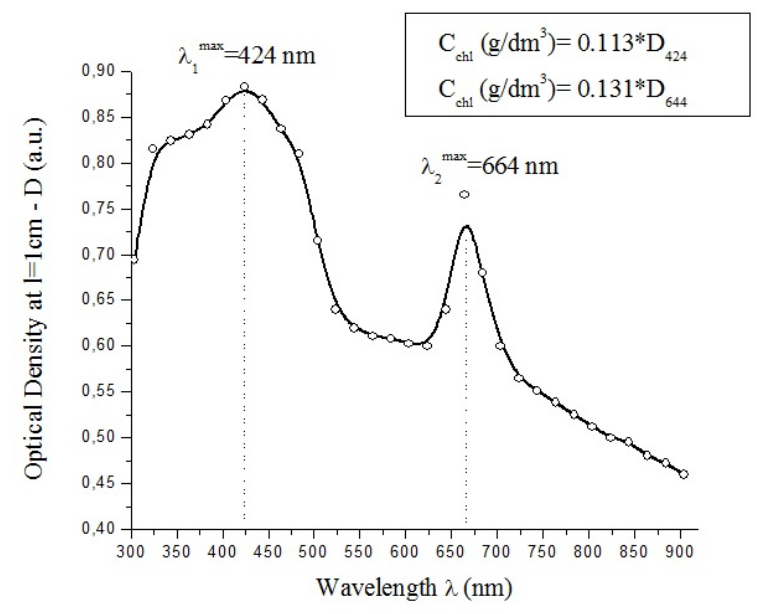

FIG. 1. Electronic spectrum of water suspension of Chlorella Vulgaris with concentration $C_{c h l}=1 \mathrm{~g} / \mathrm{dm}^{3}$ without fullerenol

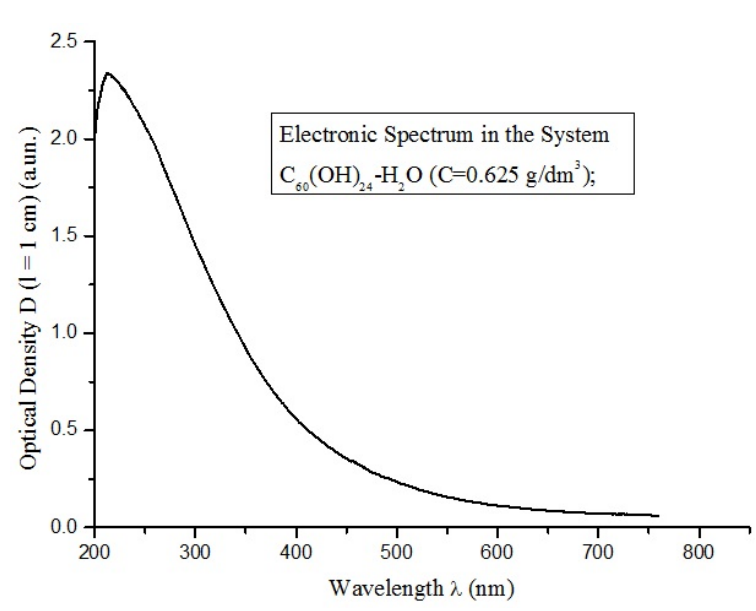

FIG. 2. Electronic spectrum of $\mathrm{C}_{60}(\mathrm{OH})_{24}$ water solution (concentration of $\mathrm{C}_{60}(\mathrm{OH})_{24} \quad-$ $C_{\text {fullerenol }}=0.625 \mathrm{~g} / \mathrm{dm}^{3}$ )

\section{Materials and experimental methods}

In the investigations we used a suspension of Chlorella Vulgaris "Detox Urban Drink" Belive Organic (Saint Petersburg, Russia) with chlorella content $1 \mathrm{~g} / \mathrm{dm}^{3}$, recalculated on solids. Also we used fullerenol $\mathrm{C}_{60}(\mathrm{OH})_{24}$, which was synthesized from Br-derivative - $\mathrm{C}_{60} \mathrm{Br}_{24}$, according to previous method [63, 64]. $\mathrm{C}_{60}(\mathrm{OH})_{24}$ was synthesized by the treatment of these product by boiling water-dioxane mixture with the dissolved $\mathrm{NaOH}$. Then sodium fullerenes forms $\mathrm{C}_{60}(\mathrm{OH})_{24-\delta}(\mathrm{ON} \alpha)_{\delta}$ were neutralized and washed in the Soxlet-extractor.

Chlorella growth or suppression were investigated in open transparent in the visible area cylindrical polystyrene test tubes at room temperature under illumination by standard incandescent lamp (Phillips E27 - 40 Wt) for the period of 9 days. Catalyst concentrations were varied in the range $0.01-1.0 \mathrm{~g} / \mathrm{dm}^{3}$. Oxidative stress was organized by the addition of hydrogen peroxide with the concentration $1.0 \mathrm{~g} / \mathrm{dm}^{3}$.

Chlorella Vulgaris concentrations were determined by the method of turbidimetry - by the determination of optical density of scattered light in the direction of propagation of the incident beam at wavelength $\lambda=664 \mathrm{~nm}-D_{664}$. The spectrum was obtained relative to the comparison solution - water solution of $\mathrm{C}_{60}(\mathrm{OH})_{24}$ with the same concentraion, that was in test suspension without fullerenol (fullerenol was not consumed during the growth of Chlorella). All suspensions were thoroughly shaken before turbidimetric determination.

A typical spectrum of chlorella water solution is represented in Fig. 1. We used the following formula to calculate chlorella concentration in suspensions:

$$
C_{c h l}\left(\mathrm{~g} / \mathrm{dm}^{3}\right)=0.131 D_{664} \quad(\text { at the width of optical cell } l=1 \mathrm{~cm}) .
$$

We do not use wavelength $\lambda=424 \mathrm{~nm}$, because the second component of the suspension substantially strengthen light absorb, when one transfers from yellow-green light to blue-violet one (Fig. 2).

The second reason of preferences of $\lambda=664 \mathrm{~nm}$ is in the fact, that this peak is considerably less diffusional (see, differential electronic spectrum in Fig. 3).

\section{Kinetics of Chlorella Vulgaris growth described by formal kinetics method}

Data on the dependence of chlorella concentration $-C_{c h l}$ against time of observation $(t)$ are represented in Fig. 4.

One can see, that all graphics $C_{c h l}(t)$ are concave, i.e. the velocity of chlorella growth decreases with chlorella concentration increases (at the same time concentration of significant participants in the process: fullerenols, visional photons, dissolved $\mathrm{CO}_{2}$ are stationary). So, the order of the reaction is negative and chlorella should be self-inhibitor of its own growth. This is atypical for standard chemical reactions, but more often is realized in some other processes, such our now, for example.

Let us determine the order of chlorella growth according to chlorella, constructed graphics for orders $n=2,1$, $-1,-2$ order for the suspension without fullerenol - Fig. 5 (graphics for $n=0$ is represented in Fig. 4). 


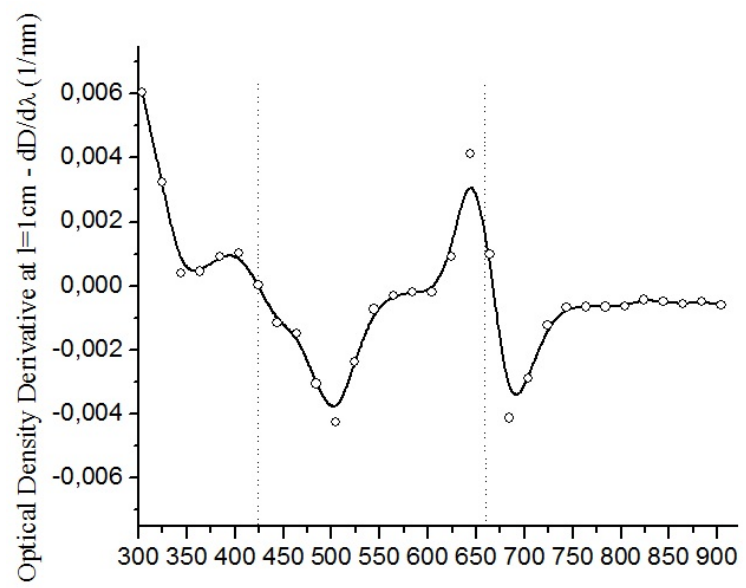

FIG. 3. Differential electronic spectrum of water suspension of Chlorella Vulgaris with concentration $C_{c h l}=1 \mathrm{~g} / \mathrm{dm}^{3}$ without fullerenol

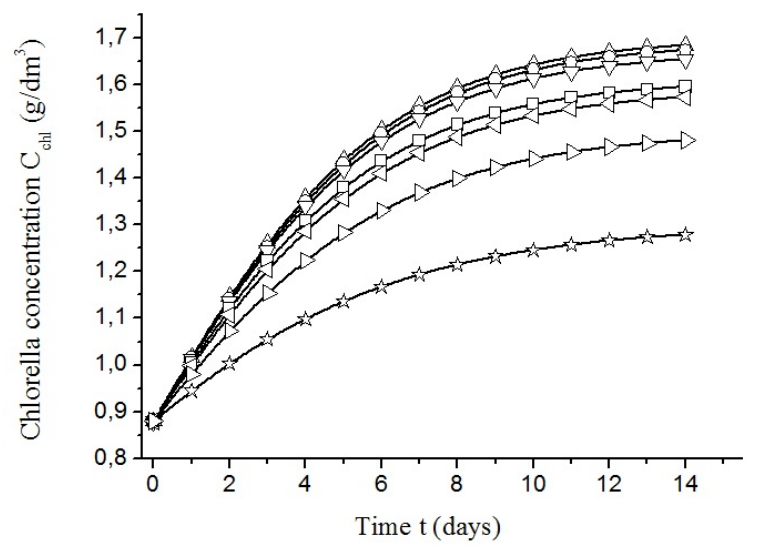

FIG. 4. Dependence of chlorella concentration $-C_{c h l}$ against time of observation $-t$ for different fullerenol concentrations $C_{\text {fullerenol }}=0.000 \mathrm{~g} / \mathrm{dm}^{3}$ (triangles with base down); 0.010 (circles); 0.0625 (triangles with base down); 0.125 (squares); 0.250 (triangles with base on right); 0.500 (triangles with base left); 1.000 (stars). Initial concentration in all cases: $C_{c h l}=0.88 \mathrm{~g} / \mathrm{dm}^{3}$

From Fig. 5 one can see, that pseudo-order of process is really nearly $n=-2$. Absolutely the same is realized in the presence of catalyst - fullerenol with all concentrations. So differential and integral kinetic equations at all fullerenol concentrations are as follows:

$$
\begin{gathered}
\frac{\mathrm{d} C_{c h l}}{\mathrm{~d} t}=K C_{c h l}^{-2}, \\
\frac{1}{3}\left(C_{c h l}^{3}-C_{c h l-0}^{3}\right)=K t .
\end{gathered}
$$

So, we determined velocity constant for the suspensions with the different fullerenol content - Table 1 and in Fig. 6 .

From Fig. 6, one can see, that at low fullerenol concentrations $C_{\text {fullerenol }}<0.1\left(\mathrm{~g} / \mathrm{dm}^{2}\right)$ it is the catalyst of chlorella growth process, but at higher concentration it is inhibitor of this process.

Unfortunately the authors are not satisfied by the presented higher calculation, because the presented experimental and calculated (according to $n=-2$ ) curves have no convex regions, where the velocity of growth increases with chlorella concentration growth. But, according to physical sense such region at low chlorella concentrations should be. In our experiment these regions were not investigated, but even if this were the case, the model of formal kinetics with the order $n=-2$ would not be able to describe this in principle.

The fact of pseudo-order $n=-2$ is not inexplicable in the conditions of limiting resources of growth, where competition between the participants of growth exists. Really:

- Dissolved $\mathrm{CO}_{2}$ is distributed evenly between chlorella and the available concentration is inversely proportional to $C_{c h l}$; 

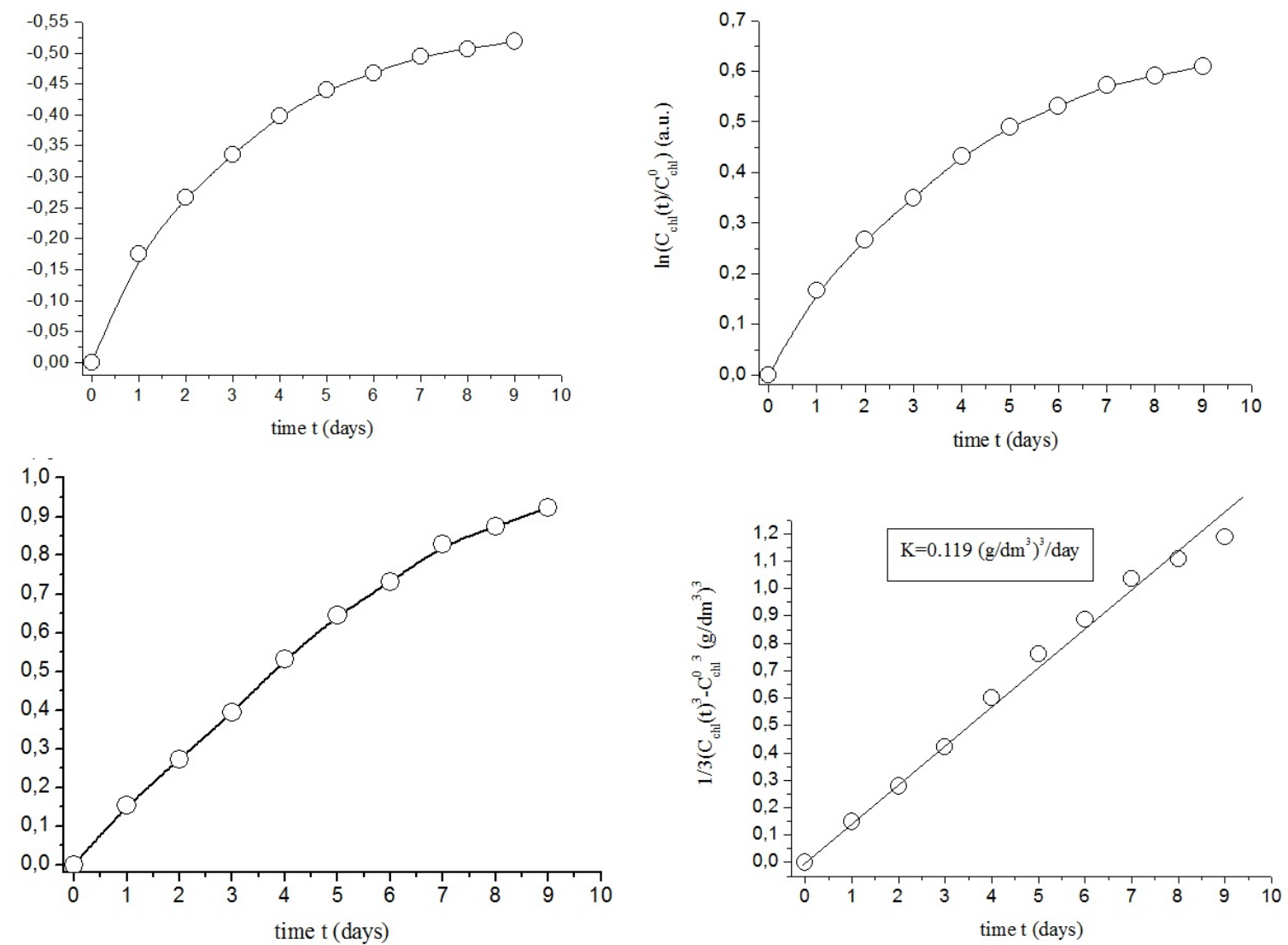

FIG. 5. Kinetic curves $F\left(C_{c h l}\right)(t)$ for different orders $n$ of the process of chlorella growth for the solution without catalyst - fullerenol (from top to bottom: $n=2$ (left-top), 1 (right-top), -1 (leftbottom), -2 (right-bottom))

TABLE 1. Velocity constants, formal integral and formal differential fullerenol activity in the process of chlorella growth (reaction of pseudo -2 order)

\begin{tabular}{|c|c|c|c|}
\hline $\begin{array}{l}\text { Fullerenol } \\
\text { concentration } \\
C_{\text {fullerenol }} \\
\left(\mathrm{g} / \mathrm{dm}^{3}\right)\end{array}$ & $\begin{array}{c}\text { Velocity } \\
\text { constant }-K \\
\left(\mathrm{~g}_{\text {chl }} / \mathrm{dm}^{3}\right)^{3} / \text { day }\end{array}$ & $\begin{array}{c}\text { formal integral } \\
\text { catalyst fullerenol } \\
\text { activity } A_{\text {fullerenol }}= \\
=K-K_{0}\left(\mathrm{~g}_{\text {chl }} / \mathrm{dm}^{3}\right)^{3} / \text { day }\end{array}$ & $\begin{array}{c}\text { formal differential catalyst } \\
\text { fullerenol activity } \\
a_{\text {fullerenol }}=\left(K-K_{0}\right) / C_{\text {fullerenol }} \\
\left(\mathrm{g}_{\text {chl }} / \mathrm{dm}^{2}\right)^{3} /\left(g_{\text {fullerenol }} \cdot \text { day }\right)\end{array}$ \\
\hline 0.000 & 0.119 & 0.000 & - \\
\hline 0.010 & 0.121 & 0.002 & 0.200 \\
\hline 0.0625 & 0.127 & 0.008 & 0.128 \\
\hline 0.125 & 0.103 & -0.016 & -0.128 \\
\hline 0.250 & 0.093 & -0.026 & -0.104 \\
\hline 0.500 & 0.073 & -0.046 & -0.092 \\
\hline 1.000 & 0.041 & -0.078 & -0.078 \\
\hline
\end{tabular}

$K_{0}$ - is velocity of chlorella growth without fullerenol. 

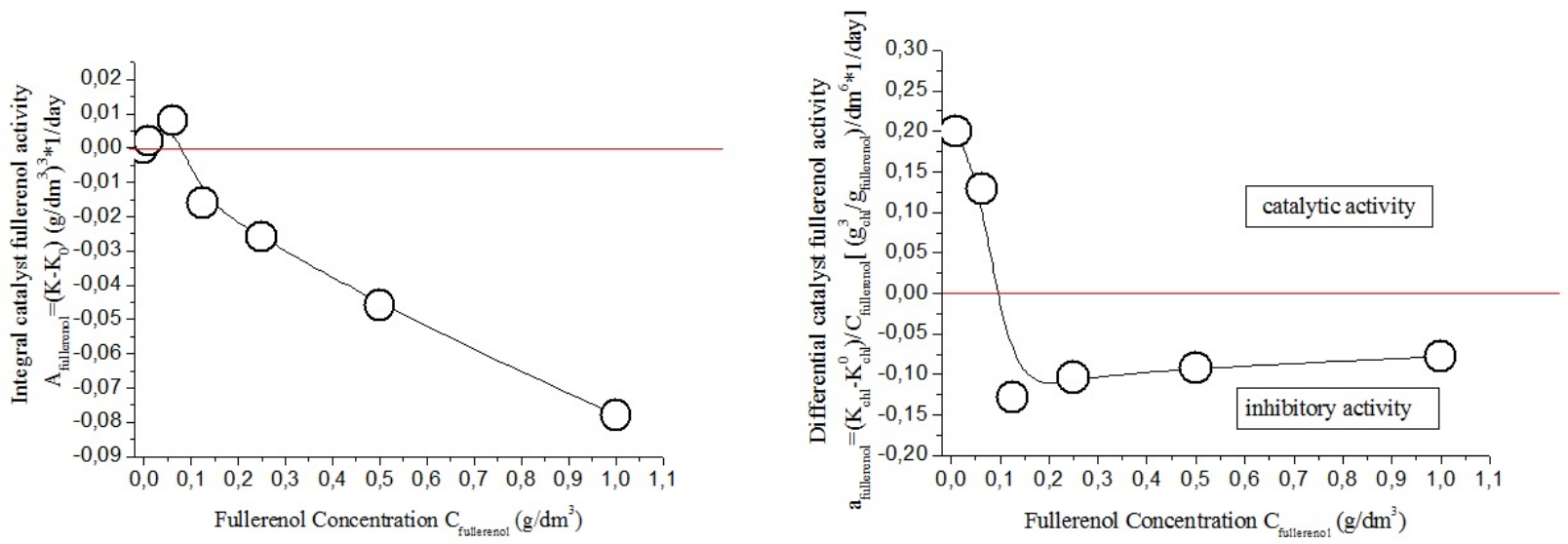

FIG. 6. Integral (left) and differential (right) catalyst fullerenol activity against fullerenol concentration

- Tested suspensions in experiments are nearly opaque for visible light (optical density at $\lambda=664 \mathrm{~nm}$ and width of optical cell in experiment $l=2 \mathrm{~cm}$ is $D_{664}=1.5-2.0$ a.u.), so from 100 photons $95-99$ photons are absorbed in the suspension. Thus, competition between chlorella for the photons also exist, and number of photons, absorbed by one chlorella also inversely proportional to $C_{c h l}$.

\section{Kinetics of Chlorella Vulgaris growth, described by Verhulst equation of logistic growth}

The Verhulst model of logistic growth $[65,66]$ was elaborated for the description of population growth in the conditions of resource constraints. Here under the term population we understand bio-mass of animals, plants, viruses, bacteria, fungi. Under limited resources we understand restricted access to food, territorial resources, access to individuals of the opposite sex for bisexual organisms, oppression or depopulation as a result of poisoning by products of metabolism. As a result, the Verhulst model describes population growth in the conditions of intraspecific competition.

The Verhulst equation has the following form:

$$
X(t)=\frac{X_{\max } X_{0} e^{r t}}{X_{\max }-X_{0}+X_{0} e^{r t}} .
$$

Where $X$ - some function, characterizing population or bio-mass, for example number of organisms, or their concentration in some normalized scale, $t$ - current time from the moment of observation start $t=0$. It is possible to extrapolate $\mathrm{t}$ in negative zone $t<0$ or for the time before observation start, and predict, for example time of population origin. Equation contains 3 parameters:

$P_{1}=X_{\max }-$ maximal population or bio-mass, corresponds to $t \rightarrow \infty$;

$P_{2}=X_{0}$ - population the moment of observation start $t=0$. Here and everywhere further we shall not consider the case, when $X_{\max }<X_{0}$, although this case maybe realized, for example in the case of sharp changes in the terms of experience;

$P_{3}=r$-initial velocity of population growth, when resource constraints are insignificant.

Two parameters $X_{\max }, r$ (as a rule are fitting ones), the third parameter $-X_{0}$ may be fitting and may be fixed (it depends on the accuracy of it's determination). If somebody wants to describe growth curve without extrapolating, possessing experimental data in whole time range, only a single parameter, $r$, may be varied.

Mathematically, the Verhulst curve is a bi-asymptotic monotonically increasing convex-concave curve with an inflection point.

Two horizontal asymptotes are the following:

$$
\lim _{t \rightarrow \infty} X(t)=X_{\max }, \quad \lim _{t \rightarrow-\infty} X(t)=X_{0} .
$$

First derivative or growth velocity may be calculated as:

$$
V=\frac{\mathrm{d} x}{\mathrm{~d} t}=\frac{X_{0} X_{\max } r e^{r t}\left(X_{0}-X_{\max }\right)}{\left(X_{\max }-X_{0}+X_{0} e^{r t}\right)^{2}} .
$$


The second derivative or growth acceleration may be calculated as:

$$
A=\frac{\mathrm{d}^{2} x}{\mathrm{~d} t^{2}}=\frac{\left(X_{0} X_{\max } r^{2} e^{r t}\left(X_{0}-X_{\max }\right)\right)\left(X_{\max }-X_{0}+X_{0} e^{r t}\right)}{\left(X_{\max }-X_{0}+X_{0} e^{r t}\right)^{2}} .
$$

This second derivative turns to 0 , at the following inflection time $-t_{\text {inf }}$ :

$$
t_{\text {inf }}=\frac{\ln \frac{x_{\max }-x_{0}}{x_{0}}}{r} .
$$

We processed obtained data $C_{c h l}$ at different catalyst - fullerenol concentrations with the help of Verhulst equation. Obtained Verhulst parameters are represented in Table 2 and I Fig. 7.

$$
\begin{aligned}
& \text { TABLE 2. Parameters of Verhulst equation of logistic growth: } C_{c h l-\max }(t)= \\
& \frac{C_{c h l-\max } C_{c h l-0} e^{r t}}{C_{c h l-\max } C_{c h l-0}+C_{c h l-0} e^{r t}}
\end{aligned}
$$

\begin{tabular}{|c|c|c|c|}
\hline $\begin{array}{c}\text { Fullerenol } \\
\text { concentration } \\
C_{\text {fullerenol }}\left(\mathrm{g} / \mathrm{dm}^{3}\right)\end{array}$ & $\begin{array}{c}\text { Verhulst equation } \\
\text { parameter } \\
C_{c h l-\max }\left(\mathrm{g} / \mathrm{dm}^{3}\right)\end{array}$ & $\begin{array}{c}\text { Verhulst equation } \\
\text { parameter } \\
r\left(\frac{1}{\text { day }}\right)\end{array}$ & $\begin{array}{c}\text { Correlation factor } \\
\text { of approximation } \\
R^{2}(a . u .)\end{array}$ \\
\hline 0.000 & 1.70 & 0.328 & 0.998 \\
\hline 0.010 & 1.69 & 0.324 & 0.982 \\
\hline 0.0625 & 1.67 & 0.323 & 0.998 \\
\hline 0.125 & 1.61 & 0.321 & 0.993 \\
\hline 0.250 & 1.59 & 0.308 & 0.995 \\
\hline 0.500 & 1.50 & 0.285 & 0.991 \\
\hline 1.000 & 1.30 & 0.240 & 0.999 \\
\hline
\end{tabular}

One can see, that the Verhulst equation quite successfully and with very low standard deviation describes dependencies $C_{c h l}(t)$ at different fullerenol concentrations. The dependencies of Verhulst parameters on fullerenol concentration is practically linear (Fig. 8) and may be approximated as:

$$
C_{\text {chl-max }}=1.70-0.40 C_{\text {fullerenol }}\left(\mathrm{g} / \mathrm{dm}^{3}\right) ; \quad r=0.328-0.088 C_{\text {fullerenol }}\left(\mathrm{g} / \mathrm{dm}^{3}\right) .
$$

So, now we can calculate the dependencies $C_{c h l}(t)$ and $V=\frac{\mathrm{d} C_{c h l}(t)}{\mathrm{d} t}$, according to Verhulst equation with parameters from Table 2 - Fig. 9,10.

One additional moment remains. Classical Verhulst curve is bi-asymptotic convex-concave curve with inflection point. One cannot see even second asymptotes, convex parts of curves (only concave), inflection points in all curves in Fig. 9. This fact can be explained easily if we take into account the fact, that we have chosen in the experiment a very high initial concentration of chlorella $C_{c h l-0}=0.88 \mathrm{~g} / \mathrm{dm}^{3}$ comparable to maximal chlorella concentrations $C_{c h l-\max }=1.3-1.7 \mathrm{~g} / \mathrm{dm}^{3}$ in dependence of fullerenol concentration (Table 2). So, convex parts of the curves should correspond to lower values $C_{c h l}$. Let us recalculate Verhulst curve into negative times (formally before start of observation) and we shall get absolutely classical Verhulst curves - Fig. 11,12.

We also calculate Verhulst integral $\left(A_{\text {fullerenol }}\right)$ and differential fullerenol catalyst activity $\left(a_{\text {fullerenol }}\right)$ in the process of chlorella growth:

$$
A_{\text {fullerenol }}=V-V_{0} ; \quad a_{\text {fullerenol }}=\frac{V-V_{0}}{C_{\text {fullerenol }}} .
$$

Calculations we provided in the form of the dependencies of fullerenol catalyst activity on time at different fullerenol concentrations and on fullerenol concentration (at fixed time of observation) - can be seen in Figs. 13,14.

From the last two figures, one can see, that fullerenol has negative catalytic activity or inhibitor activity on chlorella growth, with exception of the cases of low concentrations $\left(C_{\text {fullerenol }}\right.$ is hundredths or less than $0.1\left(\mathrm{~g} / \mathrm{dm}^{3}\right)-$ see, for example Fig. 14. For these cases, fullerenol possesses real positive catalyst activity. Moreover, for the longer the observation time, positive catalyst fullerenol activity manifests stronger. This fact corresponds to results installed previously - Fig. 6 . 

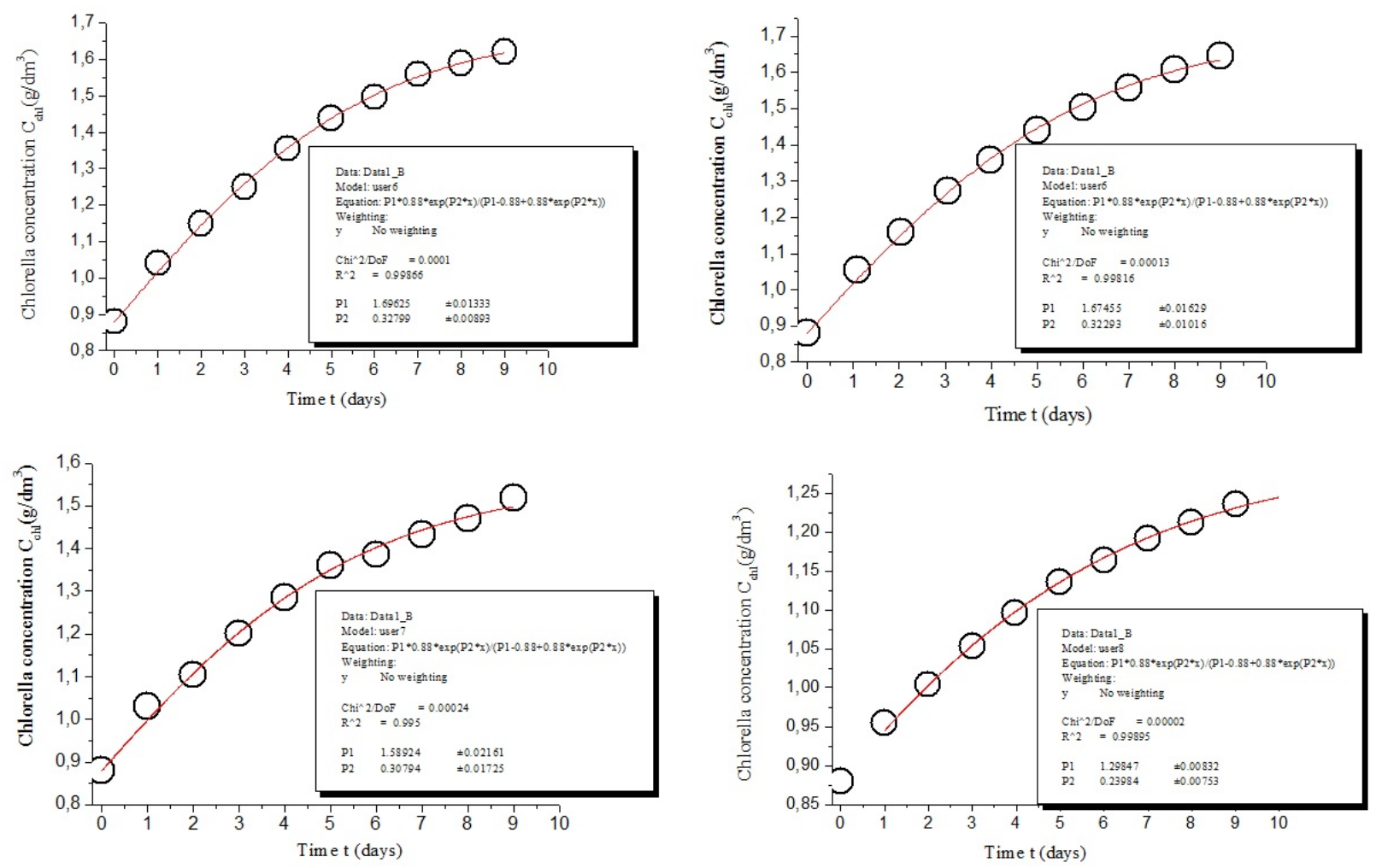

FIG. 7. Kinetic curves $C_{c h l}(t)$ and Verhulst equation approximation (red lines) for different fullerenol concentrations as an example [from top to bottom: $C_{\text {fullerenol }}=0.0$ (left-top), 0.0625 (right-top), 0.25 (left-bottom), $1.00 \mathrm{~g} / \mathrm{dm}^{3}$ (right-bottom)], $C_{c h l-0}=0.88 \mathrm{~g} / \mathrm{dm}^{3}$
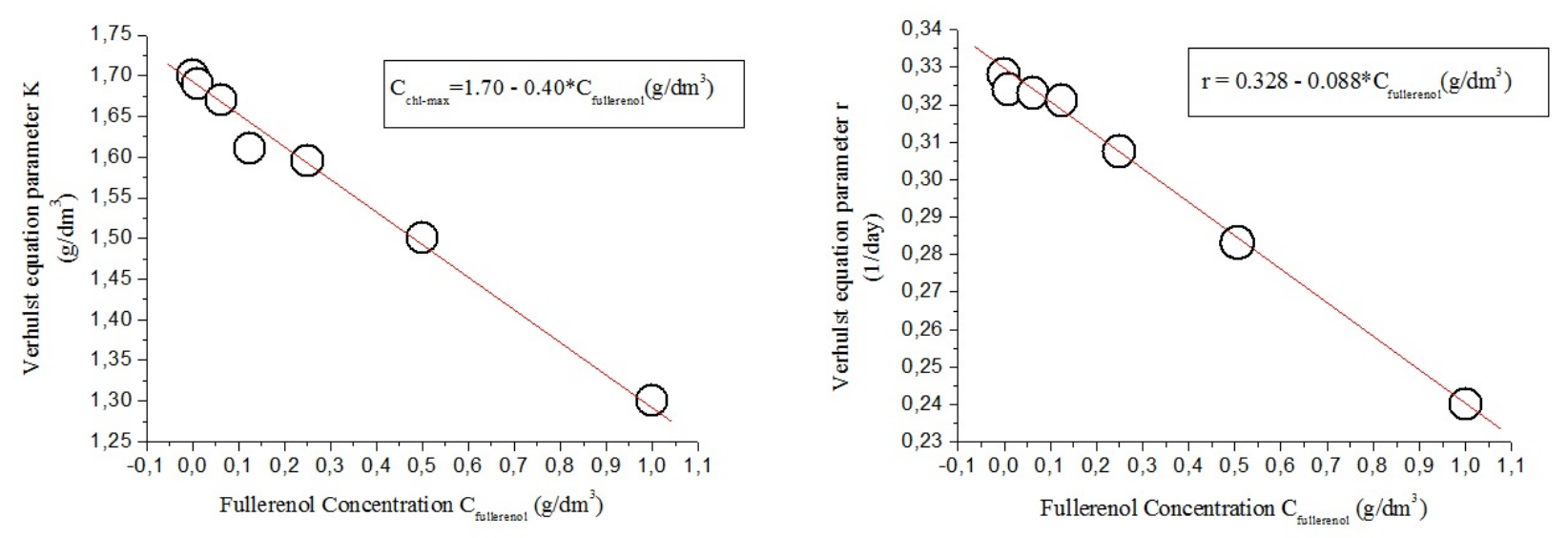

FIG. 8. Dependencies of Verhulst parameters on fullerenol concentration: $C_{c h l-\max }$ (left), $r$ (right)

\section{Kinetics of Chlorella Vulgaris growth in the conditions of oxidation stress}

Oxidative stress on the chlorella population was organized by the use of a $\mathrm{H}_{2} \mathrm{O}_{2}$ solution with a concentration $C_{H_{2} \mathrm{O}_{2}}=0.1\left(\mathrm{~g} / \mathrm{dm}^{3}\right)$ as a breeding medium for chlorella. The process of chlorella population development in this case with the use of catalyst - fullerenol, should be more complex, because there are simultaneously several multidirectional affects on this process, namely:

- Oxygen $-\mathrm{O}_{2}$ (maybe free radical - $\mathrm{O}$ : also), generated by $\mathrm{H}_{2} \mathrm{O}_{2}$ decomposition, itself is the product of chlorella metabolism, and so should inhibit chlorella population growth, or maybe cause chlorella depopulation; 


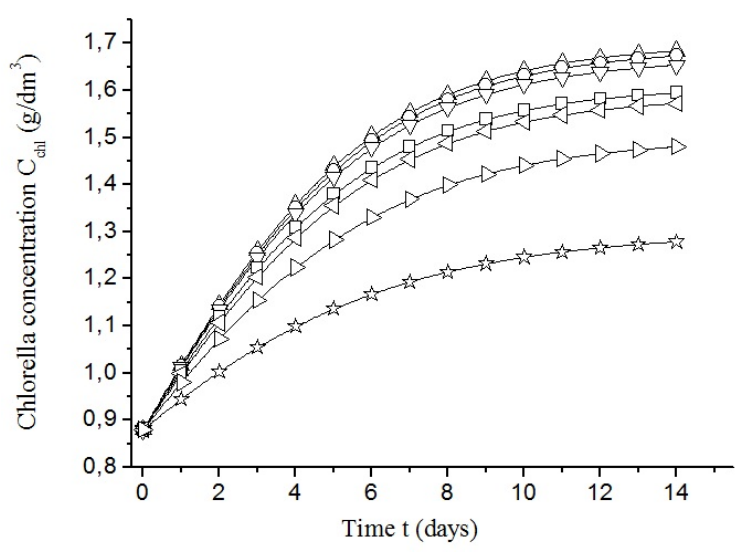

FIG. 9. Verhulst dependencies $C_{\text {chl }}(t)$ at different fullerenol concentrations $C_{\text {fullerenol }}\left(\mathrm{g} / \mathrm{dm}^{3}\right)=0.000$ (triangles with base down); 0.010 (circles); 0.0625 (triangles with base down); 0.125 (squares); 0.250 (triangles with base on right); 0.500 (triangles with base left); 1.000 (stars)

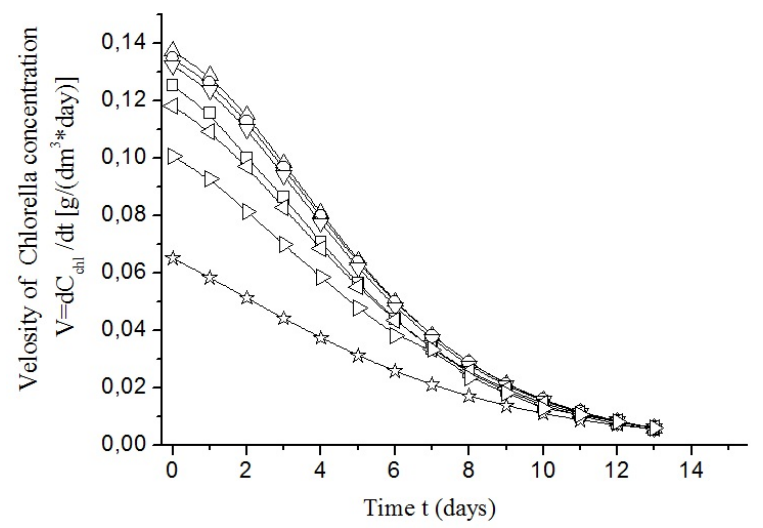

FIG. 10. Verhulst dependencies $V=\frac{\mathrm{d} C_{c h l}(t)}{\mathrm{d} t}$ at different fullerenol concentrations $C_{\text {fullerenol }}\left(\mathrm{g} / \mathrm{dm}^{3}\right)=0.000$ (triangles with base down); 0.010 (circles); 0.0625 (triangles with base down); 0.125 (squares); 0.250 (triangles with base on right); 0.500 (triangles with base left); 1.000 (stars)

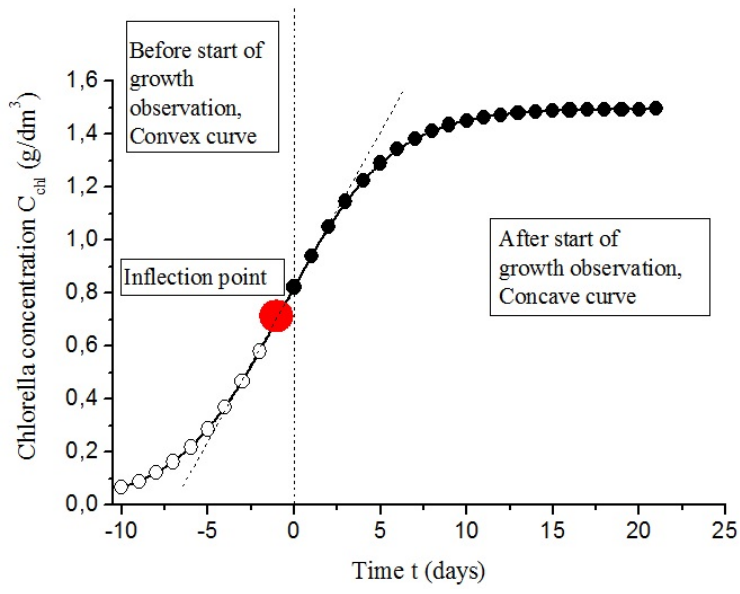

FIG. 11. Verhulst equation of logisitic growth approximation curve $C_{c h l}(t)$ (at $\left.C_{\text {fullerenol }}\left(\mathrm{g} / \mathrm{dm}^{3}\right)=0.000\right)$ with the extrapolation to the previous time 


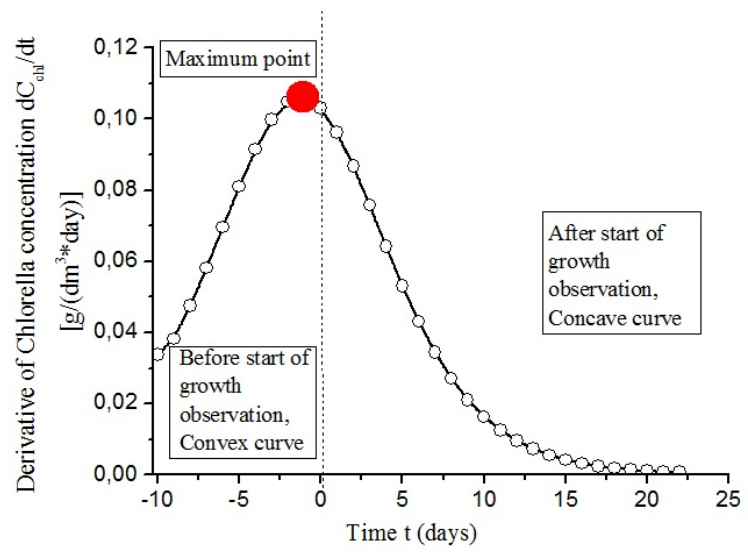

FIG. 12. Verhulst equation of the velocity of logisitic growth approximation curve $\frac{\mathrm{d} C_{c h l}(t)}{\mathrm{d} t}$ (at $\left.C_{\text {fullerenol }}\left(\mathrm{g} / \mathrm{dm}^{3}\right)=0.000\right)$ with the extrapolation to the previous time

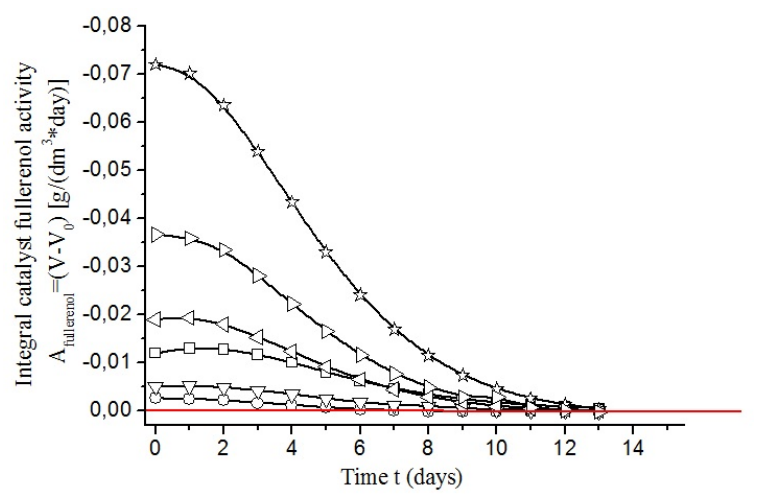

FIG. 13. Integral fullerenol catalyst activity in the process of chlorella growth at different fullerenol concentrations $C_{\text {fullerenol }}\left(\mathrm{g} / \mathrm{dm}^{3}\right)=0.000$ (red line); 0.010 (circles); 0.0625 (triangles with base down); 0.125 (squares); 0.250 (triangles with base on right); 0.500 (triangles with base left); 1.000 (stars) against time of observation

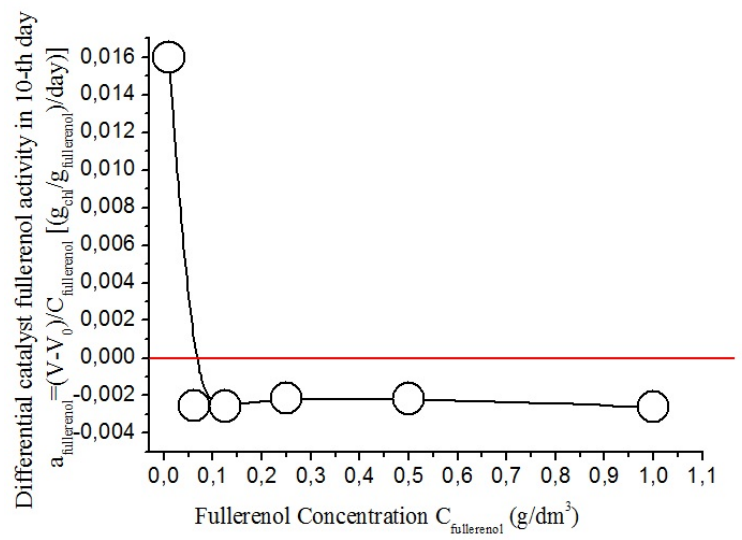

FIG. 14. Differential fullerenol catalyst activity in the process of chlorella growth on the 10-th day of observation 
- Fullerenol in low concentrations catalyzes chlorella population growth, and in higher concentrations inhibits it;

- Fullerenol at all concentrations neutralize the inhibitory action of $\mathrm{O}_{2}$, because it possesses strong antioxidant activity.

The graphics of the dependencies $C_{c h l}(t)$ at $C_{\mathrm{H}_{2} \mathrm{O}_{2}}=1.0\left(\mathrm{~g} / \mathrm{dm}^{3}\right)$ and different $C_{\text {fullerenol }}$ are in Fig. 15.

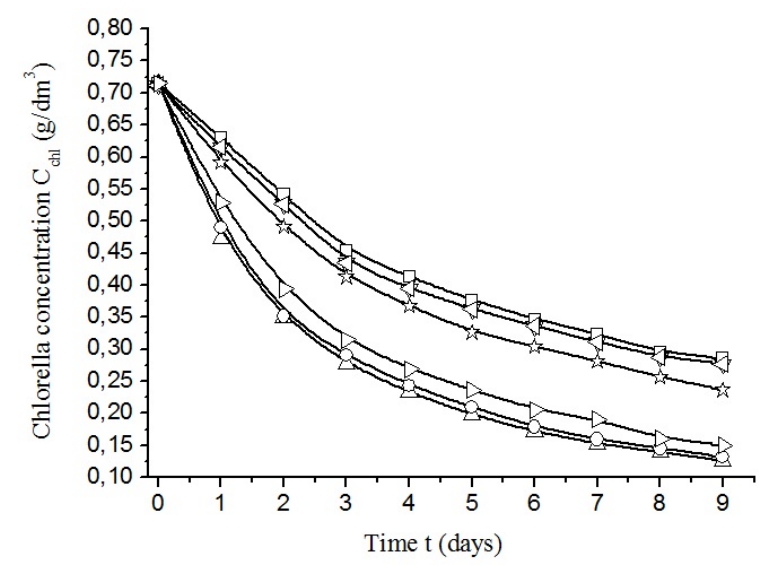

FIG. 15. Dependence of chlorella concentration $-C_{c h l}$ against time of observation $-t$ in the conditions of oxidation stress for different fullerenol concentrations $C_{\text {fullerenol }}\left(\mathrm{g} / \mathrm{dm}^{3}\right)=0.000$ (triangles with base down); 0.010 (circles); 0.0625 (triangles with base down); 0.125 (squares); 0.250 (triangles with base on right); 0.500 (triangles with base on left); 1.000 (stars). Initial concentration in all cases: $C_{c h l-0}\left(\mathrm{~g} / \mathrm{dm}^{3}\right)=0.715, C_{\mathrm{H}_{2} \mathrm{O}_{2}}=1.0\left(\mathrm{~g} / \mathrm{dm}^{3}\right)$

One can see, that in all cases curves $C_{c h l}(t)$ are monotonously decreasing, convex ones. So, we see chlorella depopulation and the order of this process should be $\mathrm{n}>1$. To determine $\mathrm{n}$ we have construct the curves for $n=1$, $n=2-$ see Fig. 16, as an example (the case $n=0$ is represented in Fig. 15).
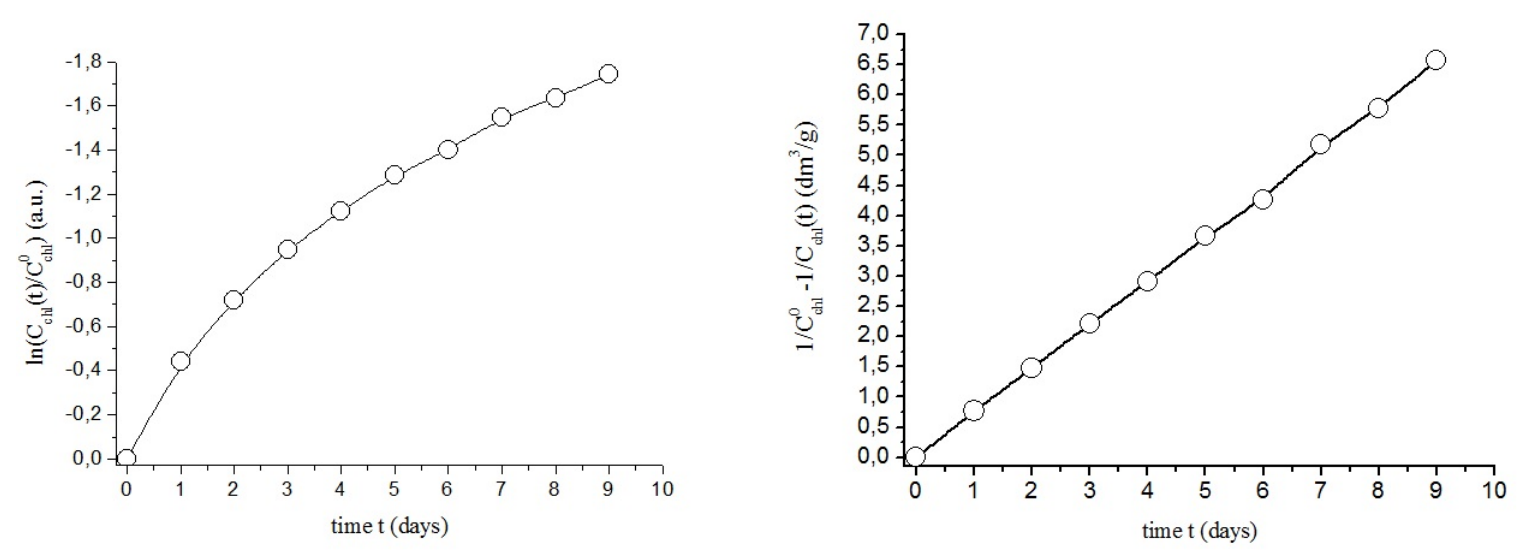

FIG. 16. Kinetic curves $F\left(C_{c h l}(t)\right)$ for different orders (n) of the process of chlorella growth for the solution with $\mathrm{H}_{2} \mathrm{O}_{2}$ and without catalyst - fullerenol ( $n=1$ (left), 2 (right))

Absolutely the same is in case of catalyst - fullerenol use. So, $n=2$, and differential and integral kinetic equation at all fullerenol concentrations are the following:

$$
\begin{gathered}
-\frac{\mathrm{d} C_{c h l}}{\mathrm{~d} t}=K C_{c h l}^{2}, \\
\left(\frac{1}{C_{c h l}}-\frac{1}{C_{c h l-0}}\right)=K t .
\end{gathered}
$$

In Fig. 17 we demonstrate how accurately eq. (12) describes the kinetics of the process at different $C_{\text {fullerenol }}$ concentrations. Calculated velocity constants for the process are represented in Table 3. 

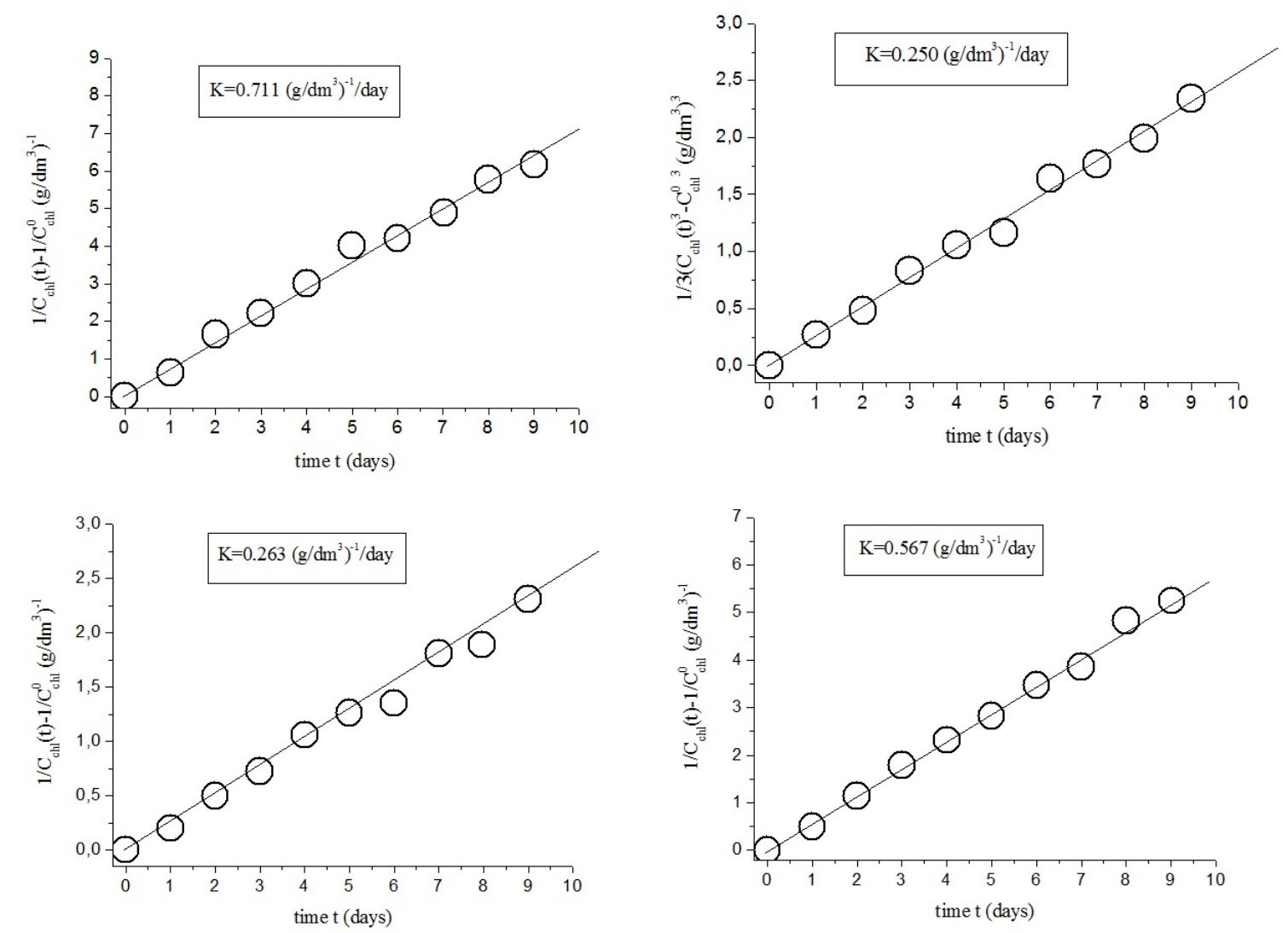

FIG. 17. Kinetic curves $\frac{1}{C_{c h l}}-\frac{1}{C_{c h l-0}}=f(t)$ for the solution with $\mathrm{H}_{2} \mathrm{O}_{2}$ and with different catalyst - fullerenol concentrations $C_{\text {fullerenol }}\left(\mathrm{g} / \mathrm{dm}^{3}\right)$ : 0.01 (left-top), 0.125 (right-top), 0.250 (leftbottom), 1.000 (right-bottom)

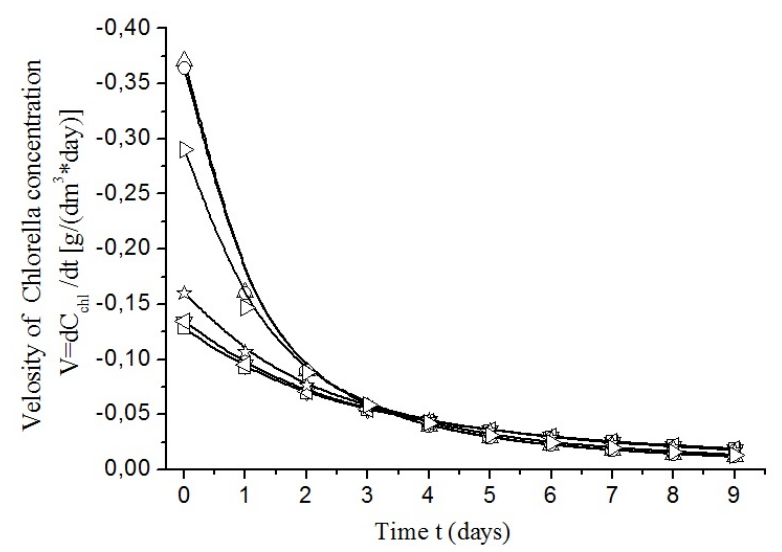

FIG. 18. Dependencies of the velocities of the process against time for different fullerenol concentrations $C_{\text {fullerenol }}\left(\mathrm{g} / \mathrm{dm}^{3}\right)=0.000$ (triangles with base down); 0.010 (circles); 0.0625 (triangles with base down); 0.125 (squares); 0.250 (triangles with base on right); 0.500 (triangles with base on left); 1.000 (stars). Initial concentration in all cases: $C_{c h l-0}=0.715\left(\mathrm{~g} / \mathrm{dm}^{3}\right), C_{H_{2} O_{2}}=1.0\left(\mathrm{~g} / \mathrm{dm}^{3}\right)$ 
TABLE 3. Velocity constants of the process of chlorella growth for the solution with $\mathrm{H}_{2} \mathrm{O}_{2}$ and with catalyst - fullerenol

\begin{tabular}{|c|c|c|c|c|c|c|c|}
\hline $\begin{array}{c}\text { Fullerenol } \\
\text { concentration } \\
C_{\text {fullerenol }}\left(\mathrm{g} / \mathrm{dm}^{3}\right)\end{array}$ & 0.000 & 0.010 & 0.0625 & 0.125 & 0.250 & 0.500 & 1.000 \\
\hline $\begin{array}{c}\text { Velocity } \\
\text { constant } \\
K\left(\mathrm{~g}_{\text {chl }} / \mathrm{dm}^{3}\right)^{-1} / \text { day }\end{array}$ & 0.725 & 0.711 & 0.263 & 0.253 & 0.625 & 0.313 & 0.567 \\
\hline
\end{tabular}

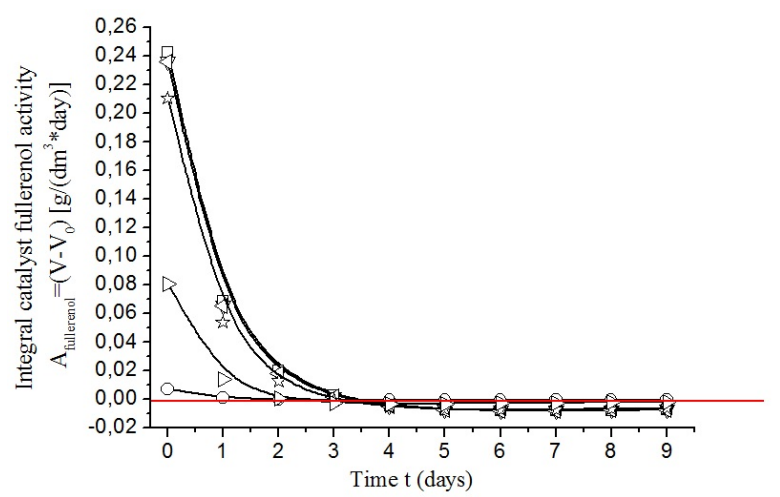

FIG. 19. Dependencies of the integral catalyst fullernol activities of the process against time for different fullerenol concentrations $C_{\text {fullerenol }}\left(\mathrm{g} / \mathrm{dm}^{3}\right)=0.000$ (base red line); 0.010 (circles); 0.0625 (triangles with base down); 0.125 (squares); 0.250 (triangles with base on right); 0.500 (triangles with base on left); 1.000 (stars). Initial concentration in all cases: $C_{c h l-0}=0.715\left(\mathrm{~g} / \mathrm{dm}^{3}\right)$, $C_{\mathrm{H}_{2} \mathrm{O}_{2}}=1.0\left(\mathrm{~g} / \mathrm{dm}^{3}\right)$

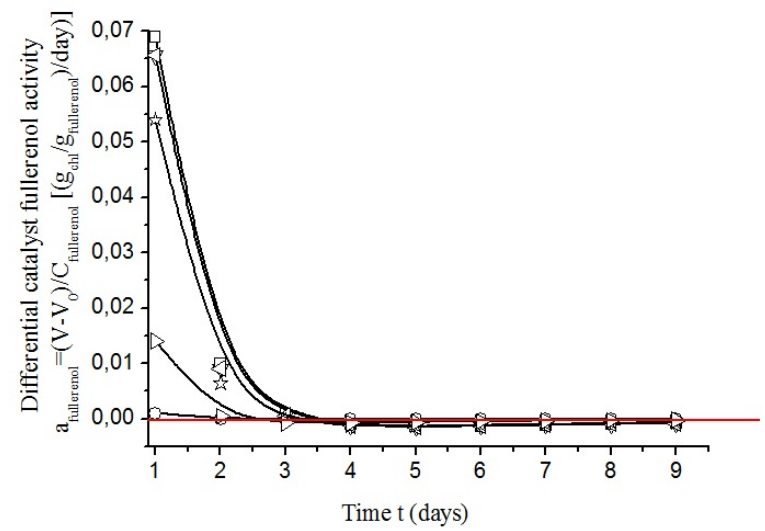

FIG. 20. Dependencies of the differential catalyst fullerenol activities of the process against time for different fullerenol concentrations $C_{\text {fullerenol }}\left(\mathrm{g} / \mathrm{dm}^{3}\right)=0.000$ (base red line); 0.010 (circles); 0.0625 (triangles with base down); 0.125 (squares); 0.250 (triangles with base on right); 0.500 (triangles with base on left); 1.000 (stars). Initial concentration in all cases: $C_{c h l-0}=0.715\left(\mathrm{~g} / \mathrm{dm}^{3}\right)$, $C_{\mathrm{H}_{2} \mathrm{O}_{2}}=1.0\left(\mathrm{~g} / \mathrm{dm}^{3}\right)$ 

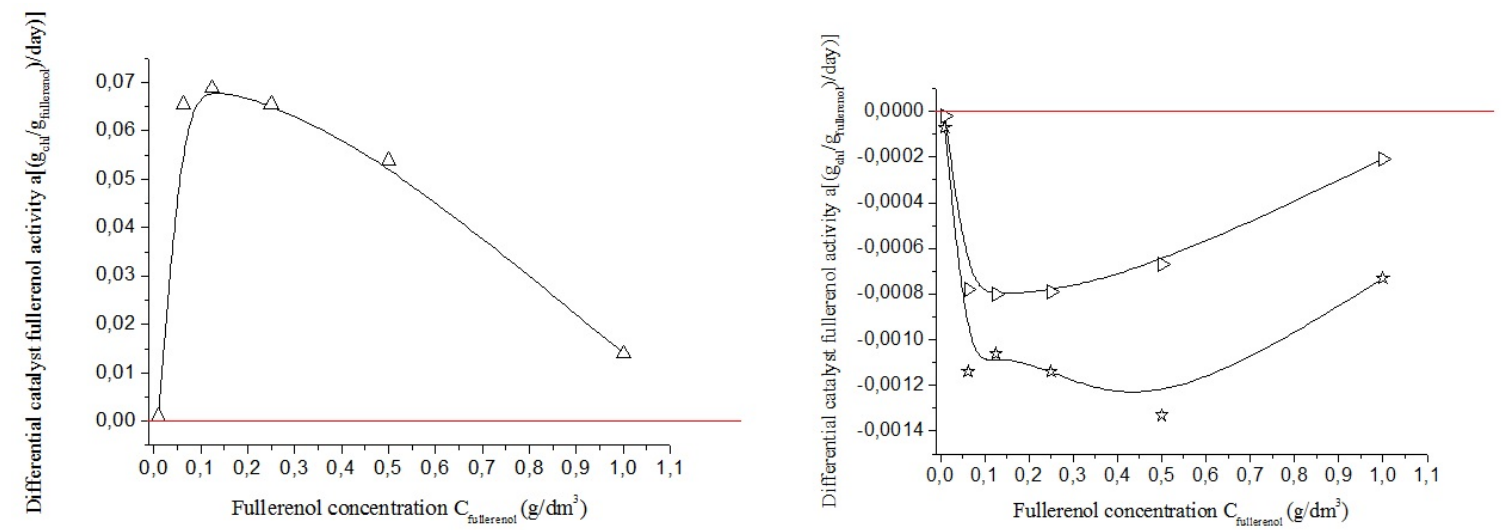

FIG. 21. Dependencies of the differential catalyst fullerenol activities of the process against fullerenol concentrations at different observation time (in days): 1-st (left); 4-th (right: triangles with base on left); 9-th (right: stars)

One can see that dependence $K\left(C_{\text {fullerenol }}\right)$ is non-monotonic and passes through the minimum, which reflects the fact, that two or more oppositely directed tendencies are acting, which increasing and decreasing of the velocity of chlorella depopulation processes. In Fig. 18 we represent the graphics of the dependencies of the velocities of the process against time for different chlorella concentrations $V=\frac{\mathrm{d} C_{c h l}}{\mathrm{~d} t}=f(t)$. Obviously the dependencies $V\left(C_{\text {fullerenol }}\right)$ are non-monotonic and also pass through the minimum, as $K\left(C_{\text {fullerenol }}\right)$ at $C_{\text {fullerenol }} \approx$ $0.10\left(\mathrm{~g} / \mathrm{dm}^{3}\right)$. We also calculated integral catalyst activity and differential catalyst activity in depopulation chlorella processes in the conditions of oxidation stress, according to eq. (10). Data are represented in Fig. 19,20, correspondingly. From Fig. 19,20, one can see, that at low observation times $0-2 \sim 3$ days fullerenol at all concentrations has an effect, inhibiting=protecting the process of chlorella depopulation, and after that - at times $2 \sim 3-9$ days this the effect is leveled and fullerenol starts catalyze=accelerate the process of chlorella depopulation.

Noticeably, it is more revealing to calculate the dependencies of differential catalyst fullerenol activities against fullerenol concentration at different fixed times of observation - see Table 4 and Fig. 21 for 1-st, 4-th and 9-th days.

TABLE 4. Integral $\left(A_{\text {fullerenol }}\right)$ and differential $a_{\text {fullerenol }}=\frac{V-V_{0}}{C_{\text {fullerenol }}}$ catalyst fullerenol activity in 1-st, 4-th and 9-th day

\begin{tabular}{|c|c|c|c|c|c|c|}
\hline $\begin{array}{c}\text { Fullerenol } \\
\text { concentration } \\
C_{\text {fullerenol }} \\
\left(\mathrm{g} / \mathrm{dm}^{3}\right)\end{array}$ & $\begin{array}{c}\text { 1-st day } \\
A_{\text {fullerenol }} \\
\left(\mathrm{g} / \mathrm{dm}^{3} \cdot \mathrm{day}\right)\end{array}$ & $\begin{array}{c}\text { 1-st day } \\
a_{\text {fullerenol }} \\
\left(\frac{g_{\text {chl }}}{g_{\text {fullerenol }}}\right) \\
/ \text { day }\end{array}$ & $\begin{array}{c}\text { 4-th day } \\
A_{\text {fullerenol }} \\
\left(\mathrm{g} / \mathrm{dm}^{3} \cdot \text { day }\right)\end{array}$ & $\begin{array}{c}\text { 4-th day } \\
a_{\text {fullerenol }} \\
\left(\frac{g_{\text {chl }}}{g_{\text {fullerenol }}}\right) \\
/ \text { day }\end{array}$ & $\begin{array}{c}\text { 9-th day } \\
A_{\text {fullerenol }} \\
\left(\mathrm{g} / \mathrm{dm}^{3} \cdot \text { day }\right)\end{array}$ & $\begin{array}{c}\text { 9-th day } \\
a_{\text {fullerenol }} \\
\left(\frac{g_{\text {chl }}}{g_{\text {fullerenol }}}\right) \\
/ \text { day }\end{array}$ \\
\hline 0.000 & 0.000 & - & 0.000 & - & 0.000 & - \\
\hline 0.010 & 0.0010 & 0.0010 & -0.00026 & -0.00007 & -0.00014 & -0.00002 \\
\hline 0.0625 & 0.0655 & 0.0655 & -0.00456 & -0.00114 & -0.00700 & -0.00078 \\
\hline 0.125 & 0.0688 & 0.0688 & -0.00422 & -0.00106 & -0.00723 & -0.00080 \\
\hline 0.250 & 0.0655 & 0.0655 & -0.00456 & -0.00114 & -0.00700 & -0.00079 \\
\hline 0.500 & 0.0539 & 0.0539 & -0.00532 & -0.00133 & -0.00607 & -0.00067 \\
\hline 1.000 & 0.0140 & 0.0140 & -0.00294 & -0.00073 & -0.00187 & -0.00021 \\
\hline
\end{tabular}

From Fig. 21, one can see, that at the time of exposition 1 day (2, 3 also) fullerenol has an effect, inhibiting = protecting the process of chlorella depopulation, and after that - at times $2 \sim 3-9$ days fullerenol starts catalyze $=$ accelerate the process of chlorella depopulation. At the same time positive fullerenol inhibitory activity at the first days according to the absolute value is 1-2 orders of magnitude greater than the negative fullerenol catalyst activity subsequently. Maximal positive fullerenol inhibitory activity corresponds to $C_{\text {fullerenol }}=0.1\left(\mathrm{~g} / \mathrm{dm}^{3}\right)$. With further increase common catalyst or inhibitory activities both quickly decreasing. 


\section{Conclusions}

Catalytic fullerenol $\mathrm{C}_{60}(\mathrm{OH})_{24}$ action on Chlorella Vulgaris growth in the conditions of limited resource growth base and in the conditions of oxidation stress were investigated. The kinetics of Chlorella Vulgaris growth in the conditions of limited resource growth, maybe adequately described by the equation of formal kinetics with a second order (inhibitory process) or Verhulst equation of logistic growth of bio-masses. It was demonstrated, that the Verhulst equation maybe satisfactorily used for the description of different natural process. The kinetics of Chlorella Vulgaris depopulation in the conditions of oxidation stress, maybe adequately described by the equation of formal kinetics of a second order. It was shown, that in the case of limited resource growth, low fullerenols concentrations $C_{\text {fullerenol }}<$ $0.1\left(\mathrm{~g} / \mathrm{dm}^{3}\right)$ catalyzes or accelerate Chlorella growth, but higher concentrations suppress or inhibit the growth. Under conditions of oxidative stress in the first $2-3$ days, fullerenols protect chlorella or inhibit depopulation; after this time, the fullerenols catalyze or accelerate chlorella depopulation. Positive fullerenol depopulation inhibitory activity at the first days according to the absolute value $1-2$ orders of magnitude greater than the negative fullerenol catalyst activity in subsequent days. Maximal positive fullerenol inhibitory activity corresponds to $C_{\text {fullerenol }} \approx 0.1\left(\mathrm{~g} / \mathrm{dm}^{3}\right)$. With further increase common catalyst or inhibitory activities both quickly decreasing.

\section{Acknowledgements}

Investigations were supported by the Ministry of Science and Higher Education of the Russian Federation (institution 785.00.X6019, mnemonic code of the application topic 0785-2021-0002).

\section{References}

[1] Sidorov L.N., Yurovskaya M.A., et al. Fullerenes. Moscow, Ekzamen, 2005, 688 p. (in Rus).

[2] Cataldo F., Da Ros T. Carbon Materials. Chemistry and Physics: Medicinal Chemistryand Pharmacological Potential of Fullerenes and Carbon Nanotubes. Springer, 2008.

[3] Piotrovskii L.B., Kiselev O.I. Fullerenes in Biology. Rostok, Saint-Petersburg, 2006, 335 p. (in Rus).

[4] Djordjevic A., Bogdanovic G., Dobric S. Fullerenes in biomedicine. Journal of B.U.ON.: official journal of the Balkan Union of Oncology, 2006, 11(4), P. 391-404.

[5] Semenov K.N., Meshcheriakov A.A., et al. Physico-chemical and biological properties of $\mathrm{C}_{60}$ - L-hydroxyproline water solutions. RSC Advances, 2017, 7. P. 15189-15200.

[6] Panova G.G., Ktitorova I.N., et al. Impact of polyhy-droxy fullerene (fullerol or fullerenol) on growth and biophysi-cal characteristics of barley seedlings in favourable and stressful conditions. Plant Growth Regulation. International Journal on Plant Growth and Development, 2016, 79(3), P. 309-318.

[7] Panova G.G., Semenov K.N., et al. Water soluble fullerene derivatives and silica nano-compositions as perspec-tive nanomaterials in plant growing. Agro-physics, 2015, 4, P. 37-48. (in Rus).

[8] Panova G.G., Kanash E.V., et al. Fullerene deriva-tives stimulate production process, growth and stability to oxidation stress for wheat and barley plants. Agricultural Biology, 2018, 53(1), P. 38-49. (in Rus).

[9] Shevchenko D.S., Rakhimova O.V., Charykov N.A., Semenov K.N., Keskinov V.A., Vorobiev A.L., Kulenova N.A., Onalbaeva Zh.S. Synthesis, identification and biotesting of water soluble octo-adduct of fullerene $\mathrm{C}_{60}$ and arginine $\mathrm{C}_{60}\left(\mathrm{C}_{6} \mathrm{H}_{12} \mathrm{NaN}_{4} \mathrm{O}_{2}\right){ }_{8} \mathrm{H}_{8} . R e p . S P b G T I(T U)$, 2018, 45, P. 77-81.

[10] Panova G.G., Serebryakov E.B., Semenov K.N., Charykov N.A., Shemchuk O.S., Andrusenko E.V., Kanash E.V., Khomyakov Y.V., Shpanev A.M., Dulneva L.L., Podolsky N.E., Sharoyko V.V. Bioactivity Study of the $\mathrm{C}_{60}$-L-Threonine Derivative for Potential Application in Agriculture. Journal of Nanomaterials, 2019, P. 1-13.

[11] Pochkaeva E.I., Podolsky N.E., Zakusilo D.N., Petrov A.V., Charykov N.A., Vlasov T.D., Penkova A.V., Vasina L.V., Murin I.V., Sharoyko V.V., Semenov K.N. Fullerene derivatives with amino acids, peptides and proteins: From synthesis to biomedical application. Progress in Solid State Chemistry, 2020, 57, P. 100255.

[12] Shevchenko D.S., Rakhimova O.V., Podolsky N.E., Charykov N.A., Semenov K.N., Keskinov V.A., Shaimardanov Zh.K., Shaimardanova B.K., Kulenova N.A., Onalbaeva Zh.S. Toxicity of water soluble octo-adduct of fullerene $\mathrm{C}_{60}$ and arginine $\mathrm{C}_{60}\left(\mathrm{C}_{6} \mathrm{H}_{12} \mathrm{NaN}_{4} \mathrm{O}_{2}\right)_{8} \mathrm{H}_{8}$. Rep. $\operatorname{SPbGTI(TU),~2019,~49(75),~P.~96-101.~}$

[13] Andrievsky G., Klochkov V., Derevyanchenko L. Is the $\mathrm{C}_{60}$ fullerene molecule toxic?! Fullerenes, Nanotubes, and Carbon Nanostructures, 2005, 13(4), P. 363-376.

[14] Aschberger K., Johnston H.J., Stone V., et al. Review of fullerene toxicity and exposure - appraisal of a human health risk assessment, based on open literature. Regulatory Toxicology and Pharmacology, 2010, 58(3), P. 455-473.

[15] Andreev S.M., Babakhin A.A., Petrukhina A.O., Romanova V.S., Parnes Z.N., Petrov R.V. Immuno-henic and allergenic properties of conjugates of fullerenes with amino-acids. Rep. Rus. Acad. of Sciences, 2000, 370(2), P. 387-399.

[16] Baati T., Bourasset F., Gharbi N., et al. The prolongation of the lifespan of rats by repeated oral administration of [60] fullerene. Biomaterials, 2012, 33(19), P. 4936-4946.

[17] Baker G.L., Gupta A., Clark M.L., et al. Inhalation toxicity and lung toxicokinetics of $\mathrm{C}_{60}$ fullerene nanoparticles and microparticles. Toxicological sciences, 2008, 101(1), P. 122-131.

[18] Costa C.L.A., Chaves I.S., Ventura -Lima J., et al. In vitro evaluation of coexposure of arsenicum and an organic nanomaterial (Fullerene C 60 ) in zebrafish hepatocytes. Comparative Biochemistry and Physiology Part C: Toxicology \& Pharmacology, 2012, 155(2), P. 206-212.

[19] Jia G., et al. Cytotoxicity of carbon nanomaterials: singl -wall nanotube, multi-wall nanotube, and fullerene. Environmental science \& technology, 2005, 39(5), P. 13780-1383. 
[20] Jung H., Wang C. U., Jang W. Nano- $\mathrm{C}_{60}$ and hydroxylated $\mathrm{C}_{60}$ : Their impacts on the environment. Toxicology and vironmental Health Sciences, 2009, 1(2), P. 132-139.

[21] Gao J., Wang H.L., Shreve A., Iyer R. Fullerene derivatives induce premature senescence: A new toxicity paradigm or novel biomedical applications. Toxicology and applied pharmacology, 2010, 244(2), P. 130-143.

[22] Horie M., Nishio K., Kato H., et al. In vitro evaluation of cellular responses induced by stable fullerene $\mathrm{C}_{60}$ medium dispersion. Journal of biochemis-try, 2010, 148(3), P. 289-298.

[23] Hendrickson O.D., Zherdev A.V., Gmoshinskii I.V., Dzantiev B.B. Fullerenes: in vivo stud-ies of biodistribution, toxicity, and biological action. Nanotechnologies in Russia, 2014, 9(11-12), P. 601-617.

[24] Hendrickson O.D., Morozova O.V., Zherdev A.V., et al. Study of distribution and biological effects of fullerene $\mathrm{C}_{60}$ after single and multiple intragastrical administrations to rats. Fullerenes, Nanotubes and Car-bon Nanostructures, 2015, 23(7), P. 658-668.

[25] Kolosnjaj J., Szwarc H., Moussa F.Toxicity studies of fullerenes and derivatives. Bio-Applications of nanoparticles, 2007 , P. 168-180.

[26] Kyzyma E.A., et al. Structure and toxicity of aqueous fullerene $\mathrm{C}_{60}$ solutions. Journal of Surface Investigation. X-ray, Synchrotron and Neutron Tech-niques, 2015, 9(1), P. 1-5.

[27] Moussa F., Chretien P., et al. The influence of $\mathrm{C}_{60}$ powders on cultured human leukocytes. Full. Sci. Technol., $1995, \mathbf{3}$, P. $333-342$.

[28] Moussa F., Trivin F., Ceolin R., et al. Ear-ly effects of $\mathrm{C}_{60}$ Administration in Swiss Mice: A Preliminary Account for In Vivo $\mathrm{C}_{60}$ Toxicity. Fullerene Science and Technology, 1996, 4(1), P. 21-29.

[29] Orlova M.A., Trofimova T.P., Orlov A.P., et al. Fullerene derivatives as modulators of cell proliferation and apoptosis. New directions in medicine science. Onco-hematology, 2012, 4, P. 7-10.

[30] Prylutska S.V., Matyshevska O.P., Golub A. at. al. Study of $\mathrm{C}_{60}$ fulllerenes and $\mathrm{C}_{60}$ - containing composites cytotoxicity in vitro. Materials Science and Engineering: C, 2007, 7(5), P. 1121-1124.

[31] Piotrovskiy L.B. Fullerenes in the design of medicinal substancies. Russian Nanotechnologies, 2007, 2(7-8). P. 6-18.

[32] Rajagopalan P., Wudl F., Schinazi R.F., Boudinot F.D. Pharmacokinetics of a water-soluble fuller-ene in rats. Antimicrobial agents andchemotherapy, 1996, 40(10), P. 2262-2265.

[33] Sayes C.M., Marchione A.A., Reed K.L., Warheit D.B. Comparative pulmonary toxicity assessments of $\mathrm{C}_{60}$ water suspensions in rats: few differences in fullerene toxicity in vivo in contrast to in vitro profiles. Nano letters, 2007, 7(8), P. 2399-2406.

[34] Trpkovic A., Todorovic, Markovic B., Kleut D., et al. Oxidative stress-mediated hemolytic activity of solvent exchange -prepared fullerene $\left(\mathrm{C}_{60}\right)$ nanoparticles. Nanotechnology, 2010, 21(37), P. 37510.

[35] Trpkovic A., Todorovic, Markovic B., Trajkovic V. Toxicity of pristine versus functionalized fullerenes: mechanisms of cell damage and the role of oxida-tive stress. Archives of toxicology, 2012, 86(12), P. 1809-1827.

[36] Yamago S., Tokuyama H., Nakamura E., et al. In vivo biological behavior of a water-miscible fullerene: $14 \mathrm{C}$ labeling, absorption, distribution, excretion and acute toxicity. Chemistry \& biology, 1995, 2(6), P. 385-389.

[37] Ueng T.H., Kang J.J., Wang H.W., et al. Suppression of microsomal cytochrome P450-dependent monooxygenases and mitochondrial oxidative phosphorylation by fullerenol, a polyhydroxylated fullerene C60. Toxicology letters, 1997, 93(1), P. $29-37$.

[38] Shipelin V.A., Arianova E.A., Trushina E.N., et al. Hygienic characteristic of fullerene $C_{60}$ while it's introducing into gastrointestinal tract of rats. Hygiene and sanitation, 2012, 2, P. 90-94.

[39] Shipelin V.A., Avreneva L.I., Guseva G.V., et al. Characteristic of oral toxicity of fullerene C 60 for rats in 92 -days experiment. Nutrition issues, 2012, 81(5), P. 20-27.

[40] Vengerovich N.G., Tyunin M.A., Antonenkova E.V., et al. Biological activity of nano-bio-composites fullerene C 60. Immunology, 2012, 12, P. 161-177.

[41] Kyzyma E.A., Tomchuk A.A., Bulavin L.A., Petrenko V.I., Almasy L., Korobov M.V., Volkov D.S., Mikheev I.V., Koshlan I.V., Koshlan N.A., Blaha P., Avdeev M.V., Aksenov V.L. Structure and toxicity of aqueous fullerene $\mathrm{C}_{60}$ solutions. J. Surf. Invest.: X-ray, Synchrotron Neutron Tech., 2015, 9(1), P. 1-5.

[42] Sayes C.M., Fortner J.D., Guo W., Lyon D., Boyd A.M., Ausman K.D., Tao Y.J., Sitharaman B., Wilson L.J., Hughes J.B., West J.L., Colvin V.L.. The differential cytotoxicity of watersoluble fullerenes. Nano Lett., 2004, 4(10), P. 1881-1887.

[43] Gao J., Wang Y., Folta K.M., Krishna V., Bai W., Indeglia P., Georgieva A., Nakamura H., Koopman B., Moudgil B. Polyhydroxy fullerenes (fullerols or fullerenols): beneficial effects on growth and lifespan in diverse biological models. PLoS ONE, 2011, 6(5), P. 1-8.

[44] Djordjevicand A., Bogdanovic G. Fullerenol: anewnanopharmaceutic? Arch. Oncol., 2008, 16(3-4), P. 42-45.

[45] Srdjenovic B., Milic-Torres V., Grujic N., Stankov K., Djordjevic A., Vasovic V. Antioxidant properties of fullerenol C $60(\mathrm{OH})_{24}$ in rat kidneys, testes, and lungs treated with doxorubicin. Toxicol. Mech. Method, 2010, 20(6), P. 298-305.

[46] Jacevic V., Djordjevic A., Srdjenovic B., Milic-Tores V., Segrt Z., Dragojevic-Simic V., Kuca K. Fullerenol nanoparticles prevents doxorubicininduced acute hepatotoxicity in rats. J. Experimental and Molecular Pathology, 2017, 3.

[47] Eropkin M.Yu., Melenevskaya E.Yu., Nasonova K.V., Bryazzhikova T.S., Eropkina E.M., Danilenko D.M., Kiselev O.I. Synthesis and biological activity of fullerenols with various contents of hydroxyl groups. Pharm. Chem. J., 2013, 47(2), P. 87-91.

[48] Golomidova I., Bolshakova O., Komissarov A., Sharoyko V., Slepneva E., Slobodina A., Latypova E., Zherebyateva O., Tennikova T., Sarantseva S. The neuroprotective effect of fullerenols on a model of Parkinson's disease in Drosophila melanogaster. J. Biochemical and Biophysical Research Communications, 2019,P. 1-6.

[49] Tyurin D.P., Kolmogorov F.S., Cherepkova I.A., Charykov N.A., Semenov K.N., Keskinov V.A., Safyannikov N.M., Pukharenko Yu.V., Letenko D.G., Segeda T.A., Shaimardanov Z. Antioxidant properties of fullerenol-d. Nanosystems: Physics, Chemistry, mathematics, 2018, 9(6), P. 798-810.

[50] Podolsky N.E., Marcos M.A., Cabaleiro D., Semenov K.N., Lugo L., Petrov A.V., Charykov N.A., Sharoyko V.V., Vlasov T.D., Murin I.V. Physico-chemical properties of $\mathrm{C}_{60}(\mathrm{OH})_{22-24}$ water solutions: density, viscosity, refraction index, isobaric heat capacity and antioxidant activity. J. of Mol. Liq, 2019, 278, P. 342-355.

[51] Tyurin D.P., Kolmogorov S.F., Cherepkova I.A., Charykov N.A., Semenov K.N., Keskinov V.A., Saf'yannikov N.M., Pukharenko Yu.V., Letenko D.G., Shaimardanov Zh.K., Shaimardanova B.K. Anti-oxidant properties of octo-adduct of fullerene $\mathrm{C}_{60}$ and L-arginine $\left(\mathrm{C}_{60}\left(\mathrm{C}_{6} \mathrm{H}_{13} \mathrm{~N}_{4} \mathrm{O}_{2}\right)_{8} \mathrm{H}_{8}\right.$. Rep $\operatorname{SPb} G T I(T U), 2019,49(75)$, P. 70-78.

[52] Grigoriev V.V., Petrova L.N., et al. Antioxidant properties of water soluble amino acid derivatives of fullerenes and their role in the inhibition of herpes virus infection. Rus. Chem. Bull. Int. Ed., 2011, 60, P. 1172-1176. 
[53] Mirkov S.M., Djordjevic, A.N., et al. Nitric oxidescavenging activity of polyhydroxylated fullerenol, $\mathrm{C}_{60} \mathrm{OH}_{24} . \mathrm{Nitric} \mathrm{Oxide}_{\mathrm{i}}$ 2004, 11, P. 201-207.

[54] Anderson R., Barron A.R. Reaction of hydroxyfullerene with metal salts: a route to remediation and immobilization. J. Am. Chem. Soc., 2005, 127(30), P. 10458-10459.

[55] Djordjevic A., Srdjenovic B., et al. Review of Synthesis and Antioxidant Potential of Fullerenol Nanoparticles. Journal of Nanomaterials, 2015, P. 567073(15).

[56] Lao F., Chen L., Li W., et al. Fullerene nanoparticles selectively enter oxidationdamaged cerebral microvessel endothelial cells and inhibit JNKrelated apoptosis. ACS Nano, 2009, 3(11), P. 3358-3368.

[57] Yin J.J., Lao F., Fu P.P., et al. The scavenging of reactive oxygen species and the potential for cell protection by functionalized fullerene materials. Biomaterials, 2009, 30(4), P. 611-621.

[58] Caputo F., De Nicola M., Ghibelli L. Pharmacological potential of bioactive engineered nanomaterials. Biochemical Pharmacology, 2014, 92(1), P. 112-130.

[59] Djordjevic A., Canadanovic Brunet J.M., VojinovicMiloradov M., Bogdanovic G. Antioxidant properties and hypothetic radical mechanism of fullerenol $\mathrm{C}_{60}(\mathrm{OH})_{24}$. Oxidation Communications, 2004, 27 (4), P. 806-812.

[60] Kokubo K. WaterSoluble SingleNano Carbon Particles: Fullerenol and Its Derivatives. InTech, 2012.

[61] Kato S., Aoshima H., Saitoh Y., Miwa N. Highly hydroxylated or cyclodextrinbicapped Watersoluble derivative of fullerene: the antioxidant ability assessed by electron spin resonance method and carotene bleaching assay. Bioorganic and Medicinal Chemistry Letters, 2009, 19(18), P. 5293-5296.

[62] Ueno H., Yamakura S., et al. Systematic evaluation and mechanistic investigation of antioxidant activity of fullerenols using carotene bleaching assaycarotene bleaching assay. Journal of Nanomaterials, 2014, 2014, P. 802596, P. 7.

[63] Semenov K.N., Charykov N.A., Keskinov V.A., et al. Solubility $\mathrm{C}_{60} \mathrm{Br}_{n}(\mathrm{n}=6,8,24)$ in organic solvents. Rus. J. Phys. Chem. A, 2009, 83(11), P. 1935-1940.

[64] Semenov K.N., Charykov N.A., Axel'rod B.M. Solubility of Bromderivatives $\mathrm{C}_{60} \mathrm{Br}_{n}$ (n = 6, 8, 24) in 1-Chloronaphthalene and 1Bromonaphthalene In Temperature Range $(10 \text { to } 60)^{\circ}$ C. J. Chem. Eng. Data., 2010, 55, P. 2373-2378.

[65] Verhulst P.F. Notice sur la loi que la population poursuit dans son accroissement. Correspondance matématique et physiqu, 1838, 10, P. 113121.

[66] Verhulst P.F. Recherches Mathématiques sur La Loi 'Accroissement de la Population Nouveaux Mémoires de 'Académi Royale des Sciences et Belles-Lettres de Bruxelles, 18, Art. 1, 1-45, 1845 (Mathematical Researches into the Law of Population Growth Increase). 